\title{
Waste Management Plan for the APT
}

by

'J.' 'L.' England

Westinghouse Savannah River Company

Savannah River Site

Aiken, South Carolina 29808

This paper was prepared in connection with work done under the above contract number with the U.S. Department of Energy. By acceptance of this paper, the publisher and/or recipient acknowledges the U.S. Government's right to retain a nonexclusive, royalty-free license in and to any copyright covering this paper, along with the right to reproduce and to authorize others to reproduce all or part of the copyrighted paper: 


\section{DISCLAIMER}

This report was prepared as an account of work sponsored by an agency of the United States Government. Neither the United States Government nor any agency thereof, nor any of their employees, makes any warranty, express or implied, or assumes any legal liability or responsibility for the accuracy, completeness, or usefulness of any information, apparatus, product, or process disclosed, or represents that its use would not infringe privately owned rights. Reference herein to any specific commercial product, process, or service by trade name, trademark, manufacturer, or otherwise does not necessarily constitute or imply its endorsement, recommendation, or favoring by the United States Government or any agency thereof. The views and opinions of authors expressed herein do not necessarily state or reflect those of the United States Government or any agency thereof.

This report has been reproduced directly from the best available copy.

Available to DOE and DOE contractors from the Office of Scientific and Technical Information, P.O. Box 62, Oak Ridge, TN 37831; prices available from (615) 576-8401.

Available to the public from the National Technical Information Service, U.S. Department of Commerce; 5285 Port Royal Road, Springfield, VA 22161. 


\section{"WFFORMATION ONLY".}

APT/PDO-97-10, RO

August 22, 1997

\section{Waste Managemenț Plan}

Accelerato

Production

of Tritium

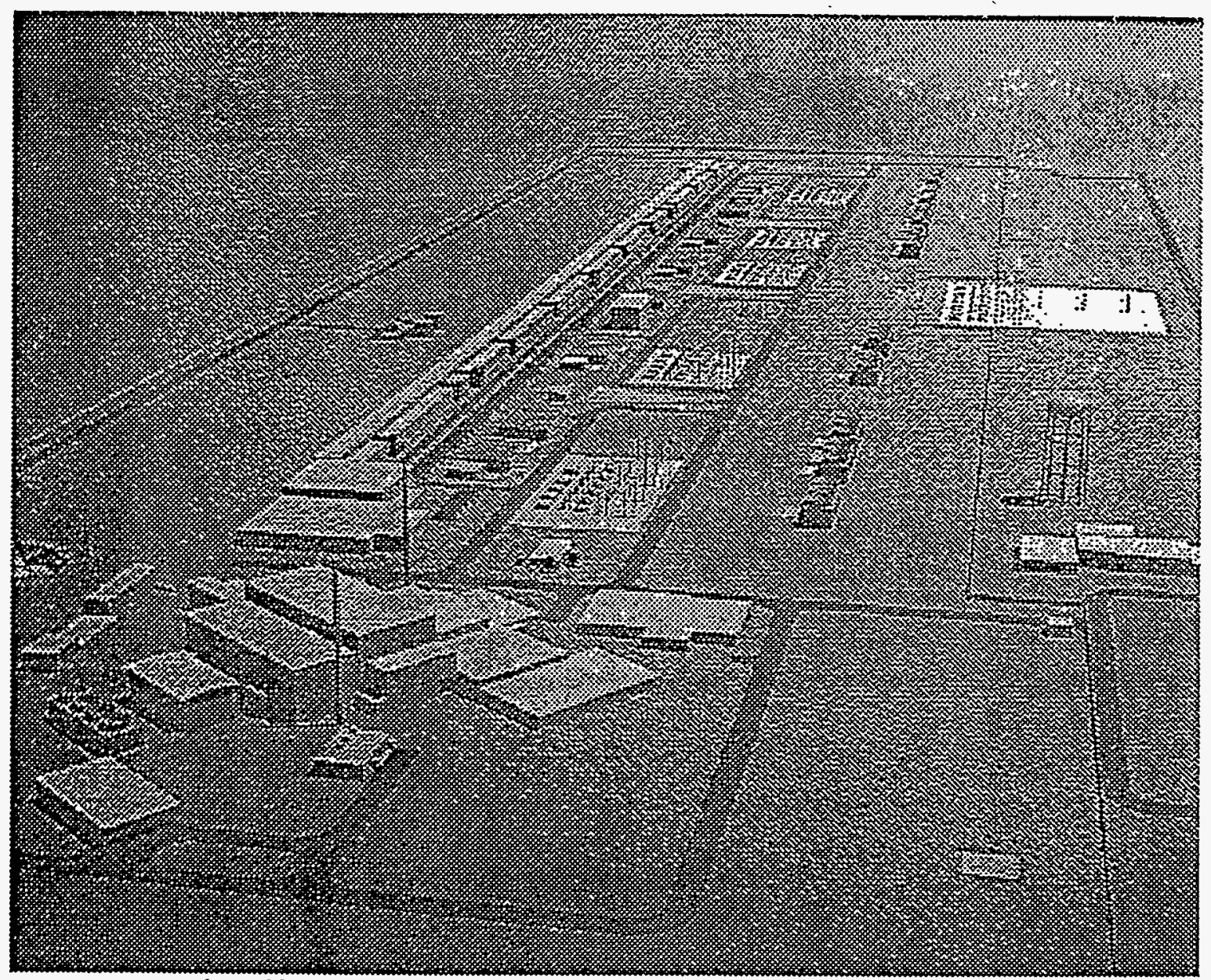

Los Alamos National Laboratory, Burns \& Roe Enterprises inc.,

General Atomics, Westinghouse Savannah River Company,

Brookhaven National Laboratory, Lawrence Livermore. National Laboratory, Sandia National

Laboratories 
MO MO
Waste Management Plan

Author

Waste' Management Team

Operations Project Office

Approval

Deputy Project Director

Operations Project Office :

Approval

Project Director

APT Project Director's Office

Origin

Originating Organization

Originating Organization Document Number

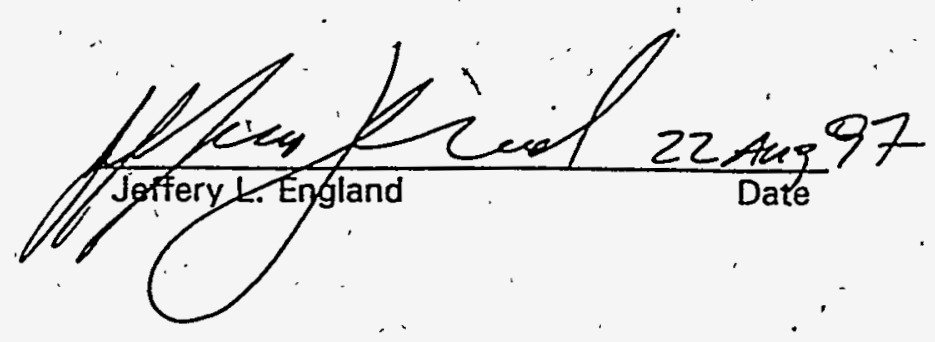

$\frac{97 Q \text { angeles } 9 / 23 / 97}{\text { J.G. Angeles }}$

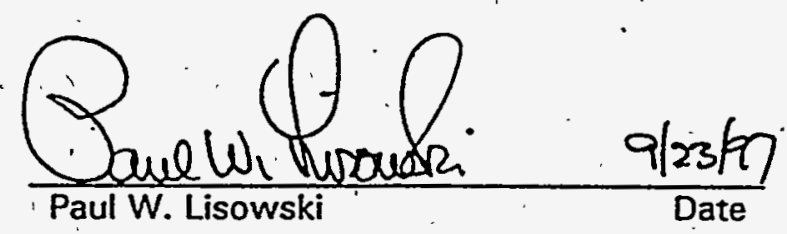

- Project Director's Office

Waste Management Plan

APT/PDO :97-10, R0. 


\section{Table of Contents}

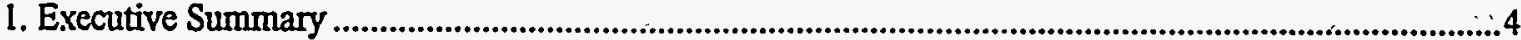

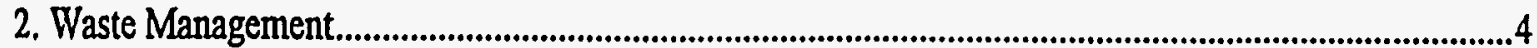

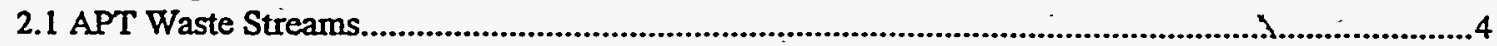

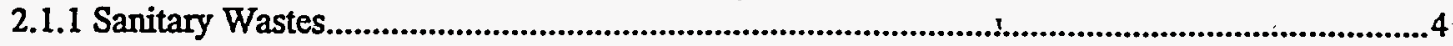

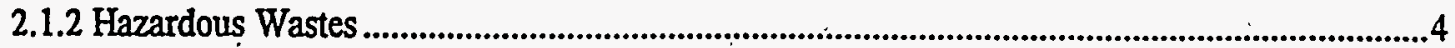

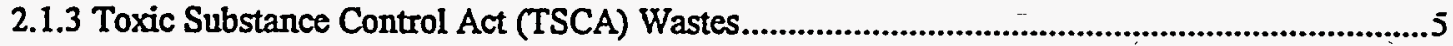

2.1.4 Low Level and Intermediate Level Radioactive Wastes...........................................................5

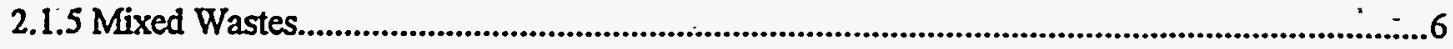

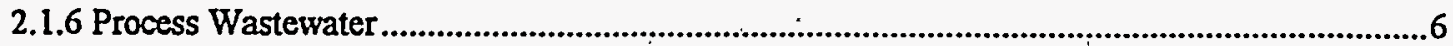

2.1.7 Stormwater Control and Outfall ........................................................................................

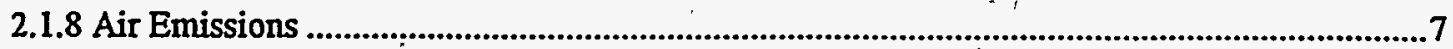

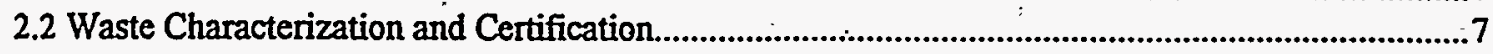

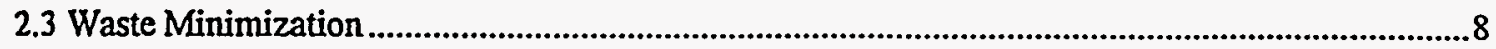

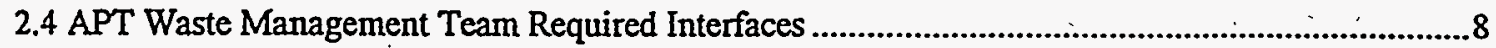

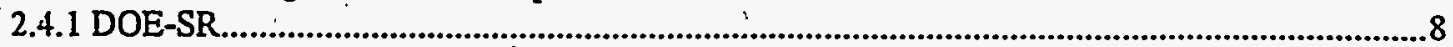

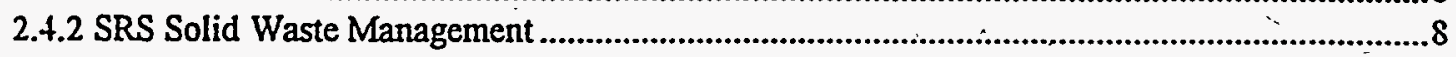

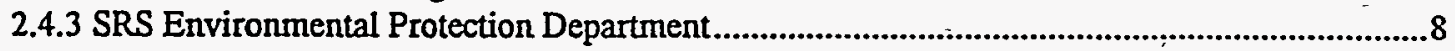

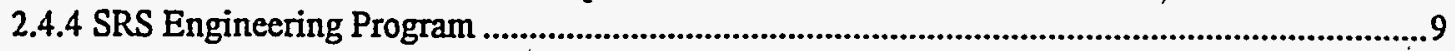

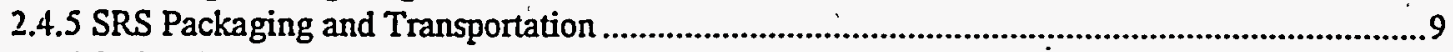

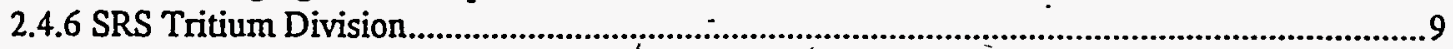

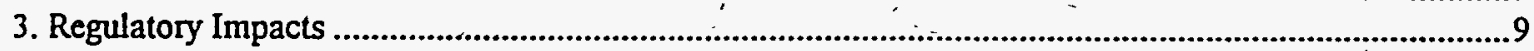

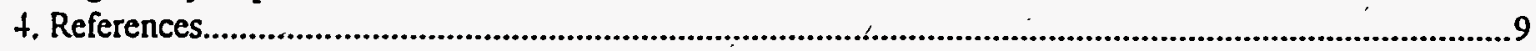

Attachment 1 - Radioactive Waste Treatment System Interfaces

Attachment 2 - APT Waste Management Facilities

Attachment 3 - APT Waste Management Issues, Responsible Organization, \& Resolution Schedules.

Attachment 4 - APT Waste Management Team Completed Tasks 


\section{Executive Summary}

This revision of the APT Waste Management Plan details the waste management requirements and issues specific to the APT plant for design considerations, construction, and operation. The.APT Waste Management Plan is by its nature a living document and will be reviewed at least annually and revised as required. This current revision will be approved by all offices of the APT project and issued by the APT Project Director. Subsequent revisions of the APT Waste Management Plan will be approved and issued by the APT Operations Project Office.

Several key issues for the APT plant are:

( A Performance Assessment (PA) for APT-generated isotopes is required for APT wastes not currently acceptable for disposal in existing SRS disposal vaults. Investigation and qualification for potential off site waste disposal locations are required for certain waste streams.

i Packaging and transport requirements for APT wastes

- The requirements, facilities, and necessary permitting actions for Resource Conservation and Recovery Act (RCRA) storage of APT mixed wastes longer than 90 days must be determined

\section{Waste Management}

SRS has a mature and capable waste management system with existing programs, facilities and disposal capability to handle over $95 \%$ of the forecasted waste from the APT plant.

\subsection{APT Waste Streams}

\subsubsection{Sanitary Wastes}

The APT plant will generate both liquid (domestic wastewater) and solid (day-to-day . garbage/construction rubble) 'sanitary waste during construction and operations. The project will provide the necessary infrastructure to tie into existing SRS sanitary waste systems. The liquid and solid sanitary waste program at SRS is capable of handling the rieeds of the APT plant.

\section{Key Issues}

S1 The APT, plant will generate solid sanitary waste initially activated by very short-lived isotopes. The specific disposal requirements for these wastes must be determined after activated material has dećayed below detection.

SRS Interfaces

0 SRS centralized sanitary waste treatment plant

[ SRS solid sanitary waste disposal contract

0 . SRS construction debris system

\subsubsection{Hazardous Wastes}

The APT plant will generate limited amounts of hazardous waste during construction and operations. The project must provide RCRA compliant satellite storage areas and provide the 
necessary infrastructure to integrate into existing SRS hazardous waste systems: The hazardous waste program at SRS is capable of handling the needs of the APT plant.

Key Issues

H1 APT will be required to design and build RCRA compliant satellite areas for hazardous waste as required to support construction, opération and maintenance activities.

\section{SRS Interfaces}

0 SRS hazardous waste program and related subcontracts

\subsubsection{Toxic Substance Control Act (TSCA) Wastes}

The APT plant has the potential to generate TSCA waste during modification, remodeling, construction, and operations of some existing facilities located in M-Area. The project will provide the necessary infrastructure to integrate into existing SRS TSCA waste systems. The.TSCA waste program at SRS is capable of handling the needs of the APT plant.

Key Issues

T1 . The actual facilities to be re-utilized in M-Area must be determined. The amounts and types of TSCA waste, if any, to be generated by the APT project must be determined.

SRS Interfaces

0 BREI as the prime construction contractor

0 SRS TSCA waste system

0 SRS construction debris system

\subsubsection{Low Level and Intermediate Level Radioactive Wastes '}

The APT plant will generate both radioactive Low Level Radioactive Waste (LLRW) and Intermediate Level Wastes (ILW) during operations and D\&D of the APT plant. The project must provide the necessary technical data and infrastructure to tie into existing SRS radioactive waste systems. The low level waste program at SRS has storage and disposal capability of LLRW and ILW.

Key Issues

$-L, 1$ The ability to assay and then certify the waste for disposal must be provided and may require unique assay equipment.

L2 A, PA for APT-generated isotopes is required for APT wastes not currently acceptable for disposal in existing SRS disposal vaults.

L3 Suitable disposal options for all APT generated long lived isotopes must be determined.

L4 For APT LLRW or ILW wastes not meeting WAC or PA requirements for disposal, the project must identify and provide any required waste treatment or packaging improvements required to meet the applicable disposal requirements.

L5 The APT plant will generate ILW waste requiring remote and non-contact handling equipment and făcilities.

L6 The.APT.plant will generate tritiated oil. This has proven to be a difficult waste . stream for SRS to treat and dispose.

L.7 . LLRW packaging requirements for shipment on and off site must be determined. 


\section{SRS.Interfaces}

D SRS LLW and ILW program and related subcontracts

Q E-Area Vaults

(] SRS long lived isotope program

0. Consolidated Incineration Facility (CIF) for any combustible LLW meeting the CIF WAC

\subsubsection{Mixed Wastes}

The APT plant will generate mixed waste (hazardous and radioactive wastes) during operations. The largest volumes, and the most significant streams, of this waste will be lead $(\mathrm{Pb})$ waste generated in the APT Target/Blanket building. The project must permit APTspecific RCRA facilities and provide the necessary infrastructure to utilize any existing SRS mixed waste system. The SRS mixed waste program currently provides RCRA permitted storage of mixed waste until treatment can be performed via methodology and schedules listed in the SRS Site Treatment Plan and the associated SCDHEC/SRS Consent Order.

Key Issues

M1 The APT plant generated mixed wastes will be incorporated into the SRS Site Treatment Plan, to be in compliance with the Federal Facility Compliance Act (FFCA)

M2 The SA'S has no permitted mixed waste disposal capability. The disposal location(s) for APT-generated mixed waste must be determined.

M3 APT-generated combustible mixed waste must be evaluated to determine if meets the WAC for the CIF.

M4 APT will be required to design and build a less than 90 day RCRA-compliant storage area to stage mixed waste.

M5 Mixed waste packaging requirements for shipment on and off site must be determined.

M6 The requirements, facilities, and necessary permitting actions for RCRA storage greater than 90 days must be determined.

SRS Interfaces.

0. SRS mixed waste program and related subcontracts

0 Mixed waste storage facilities

$0 \mathrm{CIF}$ for any combustible mixed waste meeting the CIF WAC

\subsubsection{Process Wastewater}

The APT plant will generate'significant volumes of process wastewater during operations. The project must provide the necessary facilities to store, treat, and dispose of the process wastewater generated in the operation of the APT plant or the necessary facilities to integrate with existing SRS treatment facilities.

The outfall will meet the NPDES permit limits, but there will be some residual dissolved solids and radioactive constituents in the outfall stream after all proposed treatments.

Key Issues

P1 The chemical characteristics, to include speciation, of the incoming wastewater stream must be determined.

P2 - Wastewater treatment secondary wastes (filters, spent ion exchangers, failed pumps, etc.) based on the APT wastewater treatment system design must be identified and quantified.

Waste Management Plan APT/PDO-97-10, RO 
Wastewater limits must be determined for nonradioactive constituents and established for radionuclides released to surface waters.

\section{SRS Interfaces" \\ - SRS NPDES program \\ (] PAR Pond}

\subsubsection{Stormwater Control and Outfall}

The APT plant will encompass an area of approximately $1 \mathrm{~km}^{2}$. This area must be provided stormwater controls and basins to ensure compliance with state and federal stormwater acts. Stormwater will be monitored and treated as required to meet regulations. Any water not meeting stormwater release criteria will be treated in the APT wastewater treatment plant and sent to the PAR Pond outfall.

Key Issues

None.

\section{SRS Interfaces}

[ SRS NPDES program

D APT plant. stormwater outfall

D APT process wastewater treatment system

[] PAR Pond

\subsubsection{Air Emissions}

The APT plant will generate significant volumes of air emissions during construction and operations. Under 40 CFR 61; Subpart H, and DOE' guidance the APT plant will be classified as a "major source" with stack emissions exceeding $0.1 \mathrm{mrem} /$ year Effective Dose Equivalent (EDE) at the site boundary. As a major source, the stacks will require continuous monitoring.

The project must provide this monitoring plus all other necessary permitting, monitoring, and treatment to meet the Clean Air Act (CAA).

Key Issues

A1 Air monitoring and treatment wastes (HEPA filters, spent ion exchangers, failed probes, etc.l must be identified and quantified.

A2 The air monitoring requirements need to be determined.

SRS Interfaces

D SRS CAA program

\subsection{Waste Characterization and Certification}

The APT plant must provide equipment and facilities necessary and sufficient for characterization and certification of radioactive and non-radioactive wastes.

Key Issues

W1 Determine whether it is analytically possible with existing or proposed equipment assay equipment to routinely characterize APT waste. 
W2 Determine whether certification by calculation of radionuclide distribution in, combination with streamilined sampling results is adequate for waste certification.

SRS interfaces

- SRS Waste Management

0 SRS EPD

\subsection{Waste Minimization}

The project shall comply with the following as related to waste minimization and the spread of radioactive contamination, respectively:

1. WSRC Manual 3Q, Procedure 6.11, Waste Minimization Program, and

0 WSRC 50, Chapter 4, Part 4, Solid Radioactive Waste Management.

Pollution Prevention Opportunity Assessments will be prepared for the different processes in the APT plant.. The five key steps of the method are:

1. Identify and quantify waste streams anticipated during construction, operations, and decommissioning.

2. Prioritize streams, set boundaries, and establish goals for the remainder of the design assessment.

3. Identify pollution prevention design opportunities.

4. Analyze design alternatives.

5. implement selected pollution prevention design opportunities and document results.

Key Issues

None

SRS Interfaces

SRS Waste Minimization program

\subsection{APT Waste Management Team Required Interfaces}

\subsubsection{DOE-SR}

'DOE-SR is the lead for contact with other DOE sites and DOE activities, such as the National Mixed Waste Disposal Group', to facilitate means of LLRW and mixed waste disposal off of SRS.

\subsubsection{SRS Solid Waste Management}

SRS Solid Waste Management is the primary interface-for preparation, receipt and disposition of the APT project solid waste streams, including sanitary, hazardous, low and intermediate level radioactive, TSCA and mixed wastes.

\subsubsection{SRS Environmental Protection Department}

This interface establishes the elements for compliance with environmental monitoring, surveillance and inspection, record keeping, permitting, and pollution prevention requirements. The APT project environmental coordinators interface with WSRC Environmental Protection Department (EPD) staff for guidance and support in the development of regulatory documents and permit approval packages. EPD staff will review 
and transmit all regulatory documents to appropriate permitting authority for their action and issuance/approvals.

\subsubsection{SRS Engineering Program}

The engineering program interface is used for the requirements for design of waste management facilities (storage, treatment, and disposal) outside the scope of the APT project.

\subsubsection{SRS Packaging and Transportation}

This interface establishes requirements for packaging and transportation applicable to hazardous and radioactive materials and waste shipments and storage.

\subsubsection{SRS Tritium Division}

This interface establishes.identification of tritiated waste streams and operational waste management experience within a tritium facility.

\section{Regulatory Impacts}

The design, construction, and operation of the APT plant shall be constrained as detailed in "standards" addressed in DOE Orders $5400: 1$ and 5480.4 . The standards within these two DOE Orders address waste management requirements from the following sources:

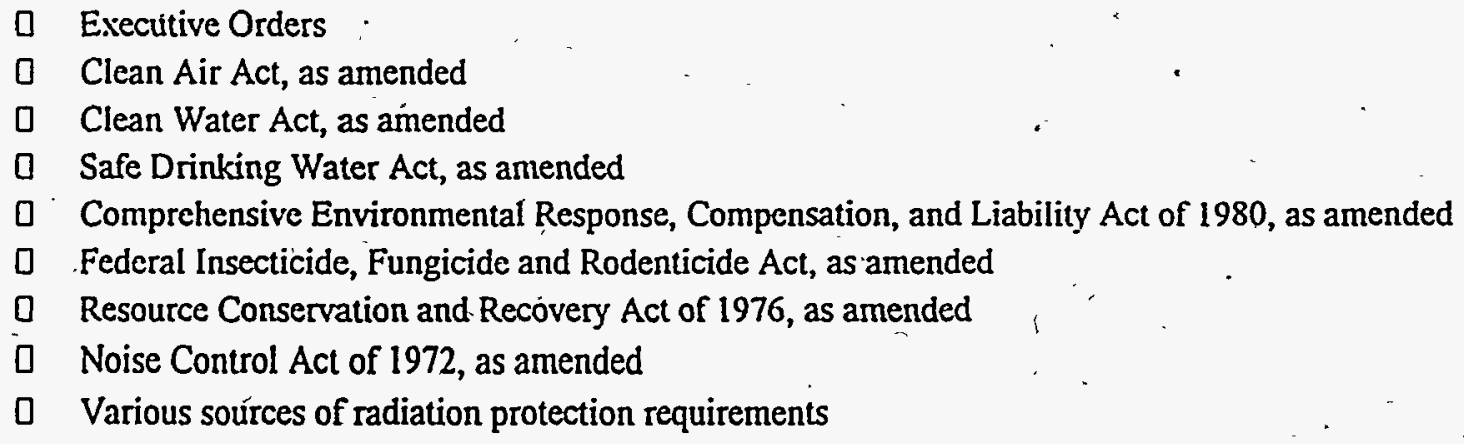

The specific sources for requirements in the APT waste management program are included in portions of DOE Order 5820.2A, the Federal Facilities Compliance Act, and the Resource Conservation and Recovery Act (RCRA), All wastes generated by this project, including construction wastes, shall be handled and disposed of in accordance with:

- WSRC 3Q, Environmental Compliance Manual

- WSRC IS, SRS Waste Acceptance Criteria Manual.

These manuals incorporate all applicable federal and state requirements for waste management at SRS.

\section{References}

1." Final Programmatic Environmental Impact Statement for Tritium Supply and Recycling, DOE/EIS-0161, Office of Reconfiguration, U. S. Department of Energy, 1000 Independence Ave., Washington, DC 20585, Attn: TSR PEIS, October 1995

2. Lọs Alamos National Laboratory Report, APT Accelerator Topical Report, Rev 1.5, LAUR-95-1480, March 1995.

-3. Los Alamos National Laboratory Report, APT Balance of Plant Topical Report, Rev 1, Rev 1. LA-CP-94-26, March 1994. 
4. Resource Conservation and Recovery Act of 1976 (RCRA), Pub. L: 94-580.

5. Comprehensive Environmental Response, Compensation, and Liability Act of 1980 (CERCLA), Púb. L. 96-510.

6. Boore, Staffing Analysis for APT Operations, January 6, 1996.

7. Reid, Subject: APT Cooling System Water Use at NTS, ESA-EPE:95-414, August 2, 1995.

8. Los Alamos National Laboratory Report No. LA-UR-95-2071, APT ${ }^{3}$ He Target/Blanket Topical Report, Revision 1.5, dated March 1995

9. Los Alamos National Laboratory Report No. LA-UR-95-3233, APT Target/Blanket Design, Revision 2, undated

10. Facility Design Description (U) for Accelerator Production of Tritium (APT) Plant, G-FDD00004.

11. Sandia National Laboratories, S.D. Carson \& P.K: Peterson, APT Project Process Waste Assessment, SAND94-2217, July 1995

12. SRS Environmental Permitting HOW Manual, WSRC-IM-91-69.

$\sqrt{ }$ 13. J.L. England, et. al., APT Pollution Prevention Design Assessment, WSRC-TR-97-0260, Draft, August 1,1997 


\section{Attachment 1 - Radioactive Waste Treatment System Interfaces}

\section{Radioactive Waste Treatment System Interfaces}

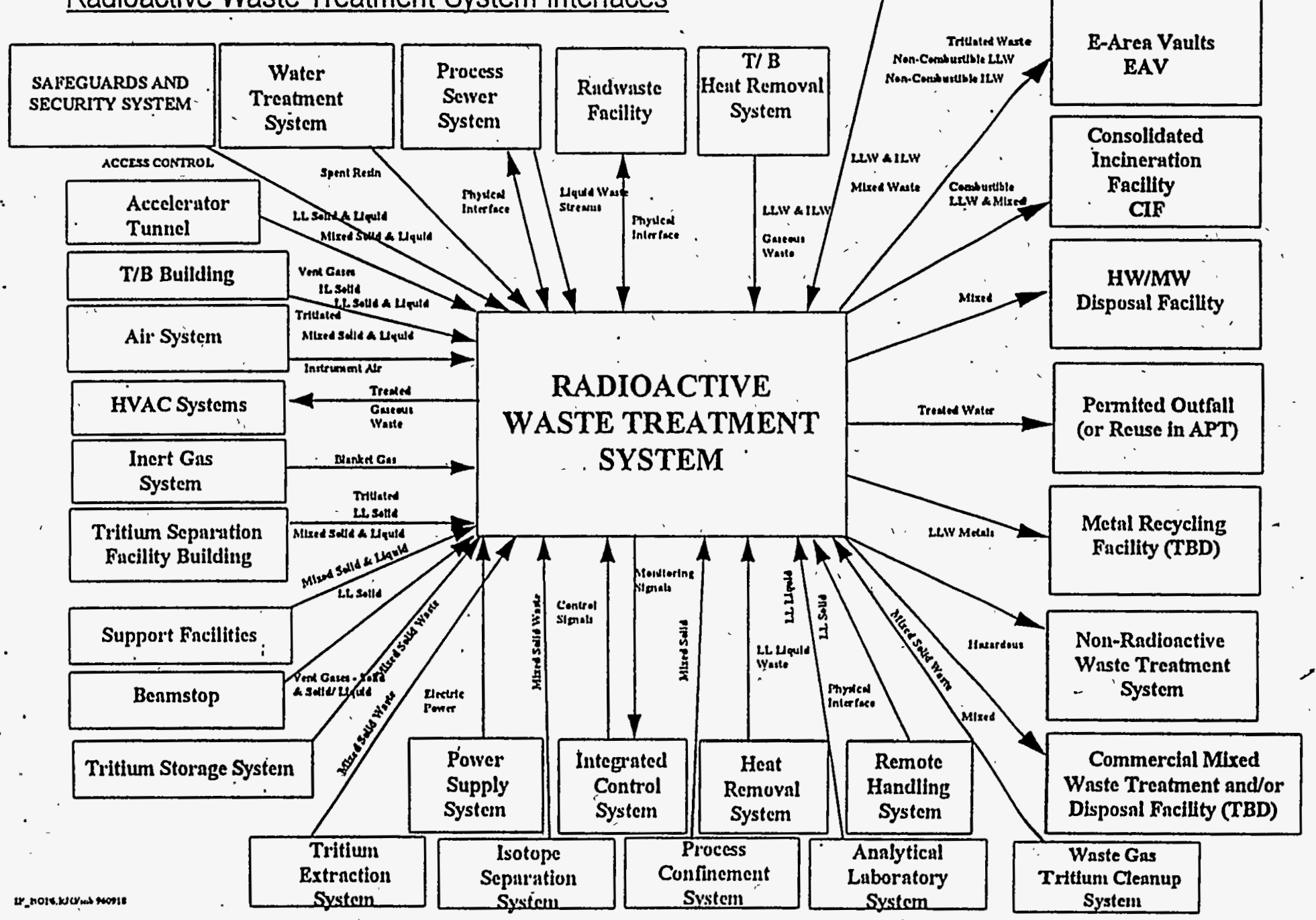


Attachment 2 - APT Waste Management Facilities

\section{APT Waste Management Facilities}

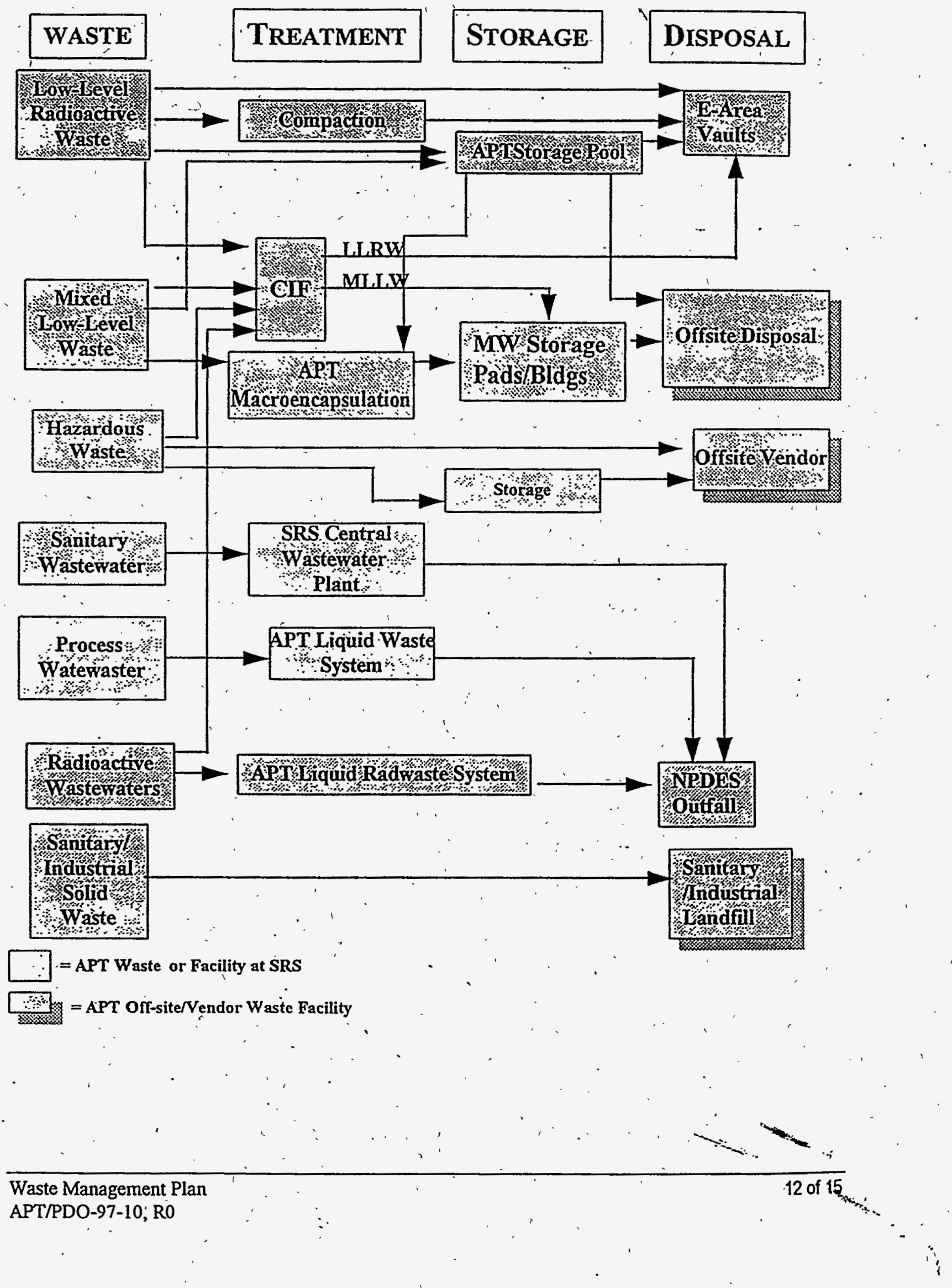


Attachment 3 APT Waste Management Issues, Waste Management Team Lead, \& Resolution Schedules

\begin{tabular}{|c|c|c|c|c|}
\hline Issue & Required Action & WMT Lead & $\begin{array}{l}\text { Start } \\
\text { Date }\end{array}$ & $\begin{array}{l}\text { End } \\
\text { Date }\end{array}$ \\
\hline S1 & $\begin{array}{l}\text { Plan for sanitary disposal of wastes } \\
\text { originally contaminated by short } \\
\text { lived isotopes }\end{array}$ & Peter Nowacki \&Jeff England & $10 / 97$ & $10 / 98$ \\
\hline T1 & $\begin{array}{l}\text { Determine TNX/F/H/M-area TSCA } \\
\text { waste generation volumes if used }\end{array}$ & Paul Lanik & $6 / 98$ & $10 / 98$ \\
\hline $\begin{array}{l}\text { L1 \& } \\
\text { W1 }\end{array}$ & $\begin{array}{l}\text { Determine assay/certification } \\
\text { techniques'\& equipment }\end{array}$ & $\begin{array}{l}\text { Richard Hane \& Maurice } \\
\text { Ades }\end{array}$ & $7 / 97$ & $2 / 98$ \\
\hline L4 & $\begin{array}{l}\text { Determine special handling or } \\
\text { packaging reqmts for waste not } \\
\text { meeting WAC }\end{array}$ & Jeff England & $10 / 96$ & $8 / 98$ \\
\hline $\begin{array}{l}\text { H1 \& } \\
\text { M5 }\end{array}$ & $\begin{array}{l}\text { Provide RCRA compliant } \\
\text { satellite/staging areas for mixed and } \\
\text { hazardous waste }\end{array}$ & Paul Lanik & 9/96 & $12 / 98$ \\
\hline L2 & $\begin{array}{l}\text { Conduct Performance assessment } \\
\text { for APT wastes }\end{array}$ & $\begin{array}{l}\text { Richard Hane, Maurice } \\
\text { Ades, \& Jeff.England }\end{array}$ & $10 / 97$ & $10 / 98$ \\
\hline L3 & Disposal of long lived isotopes " & Richard Hane & $10 / 96$ & $12 / 98$ \\
\hline L5 & $\begin{array}{l}\text { Determine remote/non-contact : } \\
\text { requirements for } 1 \mathrm{LW}\end{array}$ & $\begin{array}{l}\text { Jeff England \& Howard } \\
\text { Cohen }\end{array}$ & $3 / 97$ & $12 / 98$ \\
\hline L6 & $\begin{array}{l}\text { Develop plan for handling tritiated } \\
\text { oils }\end{array}$ & Maurice Ades & $10 / 96$ & $6 / 98$ \\
\hline $\begin{array}{l}\text { L7 \& } \\
\text { M5 }\end{array}$ & Waste Packaging Requirements & $\begin{array}{l}\text { Jeff England, Richard Hane, } \\
\text { \& Kevin Tempel }\end{array}$ & $10 / 97$ & $11 / 99$ \\
\hline M1 & $\begin{array}{l}\text { Incorporate mixed wastes into SRS } \\
\text { Site Treatment Plan }\end{array}$ & $\begin{array}{l}\text { Maurice Ades \& Kevin } \\
\text { Tempel }\end{array}$ & $1 / 99$ & $12 / 99$ \\
\hline M2 & $\begin{array}{l}\text { Identify mixed waste disposal facility } \\
\text { for APT wastes }\end{array}$ & $\begin{array}{l}\text { Maurice Ades \& Kevin } \\
\text { Tempel }\end{array}$ & $1 / 97$ & 9/98 \\
\hline M4. & $\begin{array}{l}\text { Identify combustible mixed wastes } \\
\text { that meet CIF WAC }\end{array}$ & Maurice Ades & $2 / 97$ & 9/98 \\
\hline M6 & Mixed Waste Storage & $\begin{array}{l}\text { Jeff England, Kevin Tempel, } \\
\text { \& Maurice Ades }\end{array}$ & $10 / 97$ & $12 / 98$ \\
\hline
\end{tabular}

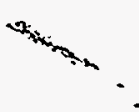




\begin{tabular}{|l|l|l|l|l|}
\hline Issue & \multicolumn{1}{|c|}{ Required Action } & \multicolumn{1}{|c|}{ WMT Lead } & \multicolumn{1}{|c|}{$\begin{array}{l}\text { Start } \\
\text { Date }\end{array}$} & $\begin{array}{c}\text { End } \\
\text { Date }\end{array}$ \\
\hline P1 & $\begin{array}{l}\text { Chemical characteristics of } \\
\text { wastewater }\end{array}$ & Howard Cohen & $9 / 97$ & $9 / 98$ \\
\hline $\begin{array}{l}\text { A1 \& } \\
\text { P2 }\end{array}$ & $\begin{array}{l}\text { Quantify secondary waste streams } \\
\text { for air \& water monitoring/treatment }\end{array}$ & Paul Lanik & $9 / 97$ & $6 / 98$ \\
\hline P3 & $\begin{array}{l}\text { Wastewater Preliminary Discharge } \\
\text { Limits }\end{array}$ & $\begin{array}{l}\text { SRS EPD and APT Waste } \\
\text { Management Team }\end{array}$ & $10 / 97$ & $12 / 97$ \\
\hline A2 & $\begin{array}{l}\text { Determine air emission.monitoring } \\
\text { requirements }\end{array}$ & Paul Lanik & $3 / 97$ & $12 / 97$ \\
\hline W2 & $\begin{array}{l}\text { Determine calculation vs. sampling } \\
\text { reqmts for WAC }\end{array}$ & $\begin{array}{l}\text { Maurice Ades \& Richard } \\
\text { Hane }\end{array}$ & $2 / 98 \cdots$ & $2 / 99$ \\
\hline
\end{tabular}

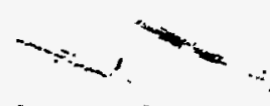




\section{Attachment 4-APT Waste Management Team Completed Tasks}

Mixed waste was the first issue addressed by the APT Waste Management Team. After evaluation of all reasonable design alternatives and materials, it was determined mixed waste generation could not be avoided. The largest volume and mass of mixed waste generated is the lead used as a neutron source in the Target/Blanket Building of the APT plant. The requirements for a RCRA permit for the storage and treatment of APT MLLW as part of the Target/ Blanket Facility would be significant schedule and cost increase for the project. Working with APT Target/Blanket and Tritium Separation Facility (TSF) designers, SRS EPD, and the South Carolina Department of Health and Environmental Control (SCDHEC), the project was able to develop a process to maximize tritium product recovery and minimize radiation exposure with the added benefit of not requiring a specific RCRA permit for storage/treatment in the APT Target/Blanket Building. The APT plant-generated lead materials will be treated and leave the Target/Blanket Building meeting the treatment requirements of the EPA Debris Rule after the maximum amount of tritium product has been extracted. The treatment options and the preferred treatments for APT mixed wastes have been documented in the APT Process Waste Assessment.

The APT WMT prepared and issued the updated Draft APT Process Waste Assessment (PWA). This . document identified and quantified all APT waste streams anticipated during construction and operations. APT wastestream radionuclide content and physical characteristics of the wastes were baselined in this document: This one document satisfied many key issues from the 9 . Oct 96 APT Waste Management Plan and is being used as the source document for.EIS input.

The APT WMT provided waste estimates for all APT-generated wastes for use in forecasting requirements to the SRS waste management divisions to integrate its needs with future capacity and programs.

Staging or interim storage facilities for high radiation wastes were incorporated into the APT Conceptual Design Report (CDR) for radioactive waste in order to meet the rem rates required to meet disposal facility waste acceptance criteria.

The APT WMT updated operational waste estimates and decommissioning waste volumes and their associated costs for the APT CDR.

Tritiated $\mathrm{D}_{2} \mathrm{O}$ will be cleaned to the maximum extent of other radionuclide contaminations and stored for tritium decay and eventual reuse. 